\title{
TECHNICAL EFFICIENCY HETEROGENEITY OF TERTIARY INSTITUTIONS IN VIET NAM: A METAFRONTIER DIRECTIONAL TECHNOLOGY APPROACH
}

\author{
Renato A. VILLANO ${ }^{1^{*}}$, Carolyn-Dung Thi Thanh TRAN ${ }^{2,3}$ \\ 1, 2 UNE Business School, University of New England, Armidale, NSW 2351, Australia \\ ${ }^{3}$ International College of Management Sydney, Manly, NSW, 2095 Australia
}

Received 01 July 2017; accepted 20 August 2018

\begin{abstract}
The higher education system of Viet Nam has been undergoing reform process with the aim of seeking a position in the world's education market. However, recent changes in the system have made the operational efficiency of the system less stable, thus making it more challenging to improve the country's universities world rankings. In this paper, we investigate the performance of tertiary education institutions in Viet Nam and evaluate the efficiency gap between colleges and universities. Using the metafrontier directional technology approach, we estimate both the group frontier and metafrontier efficiencies for 112 universities and 141 colleges using data for 2011-2013 and compute their differences imposed by the technology associated with different levels of ownership and locations. The findings showed that the performance of universities were better than that of colleges, at 0.8370 .774 , respectively. However, under an unrestricted metafrontier framework, the metatechnology ratios suggest that universities and colleges were operated comparatively well by potentially increasing their performance by 7.8 and 5.0 per cent, respectively. Both urban universities and colleges are found to be more efficient than their rural counterparts, but the effects of ownerships showed mixed results on the performance of universities and colleges. Our results highlight the need for appropriate policies and enabling environment that will enhance the performance of each institution. It is imperative to re-evaluate the specific role and individual contributions of colleges and universities in the national education system and assist rural universities and colleges to explore their full potential to enhance their performance.
\end{abstract}

Keywords: data envelopment analysis, directional distance, higher education institutions, metafrontier, technological heterogeneity.

JEL Classification: C61, D24, I23.

\section{Introduction}

The efficiency of the higher education sector has been one of the central themes of many studies because of its importance in socio-economic development. Performance of the higher education sector is a crucial indicator for enhancing the competitive ability of a nation

${ }^{\star}$ Corresponding author. E-mail: rvillan2@une.edu.au

This is an Open Access article distributed under the terms of the Creative Commons Attribution License (http://creativecommons. org/licenses/by/4.0/), which permits unrestricted use, distribution, and reproduction in any medium, provided the original author and source are credited. 
(Schwab, 2013). For developing countries, enhancing efficiency of the education sector, especially higher education, is very important to improve the competitive capacity of the nation and rankings of its tertiary education institutions (TEIs).

Viet Nam, as a case of developing nation, has emerged as one of the fastest growing economies in the world after nearly 30 years of implementing the Doi Moi (renovation) policy in 1986. The gross domestic product of Viet Nam has attained a growth rate of more than seven per cent per annum, on average, during the period 1989-2010 (World Bank, 2011). Income per capita per annum increased from US $\$ 170$ to US\$620 in 2005 and roughly US\$1,900 in 2013 (Muszynski, 2008; Pham, 2011; Government Statistics Office, 2013). It can be seen that Vietnam has achieved great achievements in implementing its reform policy in terms of remarkable economic growth and a significant improvement in social welfare. This impressive performance has been highly recognized by the international community (Glewwe, 2004; Nguyen \& Tran, 2009).

Economic reforms in Viet Nam are strongly linked to its higher education sector. Under the Doi Moi (renovation) policy, private education was permitted and encouraged. This allowed private organizations and individuals to invest in the national education system. Subsidies on education were gradually removed. The government and the community together shared fees to access educational services and thus develop the national education system in a market orientation (Pham, 2011; London, 2010). Currently, Viet Nam had a total of 442 TEIs in 2016, of which 90 were private including 60 private universities and 30 private colleges. Among the 352 public TEIs, there were 163 public universities (Ministry of Education and Training [MOET], 2016). In addition, 50 per cent of the 442 TEIs are located in urban cities such as Hanoi capital, Hochiminh City and Danang City. The number of students grew sharply at 2,202,732 students in 2015/2016, nearly 2.5 times higher than that in 1999/2000. An increase in the numbers of TEIs and students is considered as being a good signal for the renovation process of higher education in Viet Nam. Along with this, several policies were issued to favour educational operations of TEIs, especially the policy on comprehensive reform of higher education (Higher Education Reform Agenda [HERA]), that made significant contributions to the productivity growth of the higher education system. However, in order to keep pace with the world's higher education standards and achieve the government's efforts to get at least one university into the world's top ranked universities by 2020 , it is important for TEIs to have stable performance in terms of enhancing their productive efficiency in their academic operations.

The Vietnamese higher education system consists of universities (including research institutes) and colleges. Although universities and colleges are both categorized as TEIs under the education law, ${ }^{1}$ they are operating under relatively different environments. Whereas undergraduates at universities are trained for a period of four years, those in colleges are trained for only three years. Only universities offer postgraduate programs. Moreover, research outputs of universities focus on academic research but those of colleges are primarily related to research of technological transfers and consultant services. Finally, colleges tend to train students with more practical skills whereas universities teach students research skills.

\footnotetext{
${ }^{1}$ Education Law was approved by the Vietnamese National Assembly, Batch VIII on 18 June, 2012.
} 
It is noted that college students who want to get a degree need to study for a further one to one and a half years to fill a gap in the curricula between universities and colleges. Moreover, there is a significant difference in the use of input resources between universities and colleges, where universities are found to have used higher inputs than colleges as indicated in Appendix, Table A1. These differences show that the teaching technologies, referred to as the study objectives, skills and duration, of universities and colleges are not similar in their academic operations, and, thus, their operational efficiency should be evaluated and compared within their own cohorts.

Recently, more colleges have applied for an upgrade to university status because this was believed to be more advantageous for them in increasing the number of new enrolments and developing new specialisations to meet the demands of learners. There is no formal policy and conditions for upgrading a college to a university, as such, but colleges that wishes to be upgraded to universities, generally follow Decision 64/2013/QD-TTg ${ }^{2}$ issued by the government in 2013 including conditions for establishment, permission and suspension of training activities, merger, division, separation or dissolution of universities or institutes.

Policy makers argued that both universities and colleges play crucial roles in the national education system to provide knowledge for learners and meet the requirements of socioeconomic development (Hoang, 2013; Pham, 2013). The main aim of the Government is to have an efficient higher education system, in which universities and colleges can deliver their respective programs in their own respective teaching environments. In principle, colleges are able to be upgraded to universities if they meet requirements of academic staff, teaching and learning facilities and education quality to produce better outputs as indicated above. However, the sector still faces major challenges in achieving their full potential because of some constraints imposed by restrictions on resources, regulations, and contextual factors such as ownership and location. Therefore, whether upgrading a college to the university status is worth pursuing is suspicious and need to be answered. In this sense, understanding the technological heterogeneity and the operational efficiencies of universities and colleges, and identifying potential bottlenecks would be helpful to orient education policies in the right direction and, thus, allow the policymakers to act on the specific needs required to improve the performance of TEIs.

To address the above mentioned problem, the research objective of this paper is to investigate the gap in teaching technology and in the efficiencies of universities and colleges over the period 2011-2013. This gap is not only due to the inherent nature of universities and colleges themselves but the policy environment as well. Given that the mandate provided to each of these sectors, it is imperative to examine the efficiencies of universities and colleges with respect to their own teaching technologies and that of the whole sector. This paper focuses on technical efficiency in operations of TEIS rather than education quality that

\footnotetext{
2 The key conditions of establishing a university include (1) a proposal of establishing a university that meets requirements of socio-economic development and higher education network development plan of 2006-2020; (2) an approval of local authority for establishing a university in the region; (3) land for campus not less than five hectares and on average $25 \mathrm{~m}^{2} /$ student for academic spaces for learning; (4) for public universities, a clarity of financial resources to conduct the plan and for private universities, at least 250 billion VND for operational capital (excluding the value of land for building campus); and (5) sufficient academic and management staff, especially academic staff with $\mathrm{PhD}$ qualification. Once these conditions are satisfied, colleges can be upgraded to the university status.
} 
refers to effectiveness of teaching process including teaching quality of academic staff and learning quality of students. In reality, it is widely recognised that once performance of TEIs is efficient, it will be strong incentive for further improvement in education quality.

In doing so, we integrate the data envelopment analysis (DEA) metafrontier framework into the directional distance technology to evaluate the heterogeneity in teaching technology and efficiencies between the two groups, namely, universities and colleges. The directional distance approach is more flexible than the traditional input or output distance function because it allows one to seek for simultaneously expanding outputs and contracting input resources (Simar, Vanhems, \& Wilson, 2012). By integrating the directional distance function into DEA metafrontier framework, the operational efficiencies of universities and colleges are estimated in terms of their respective group frontier and a metafrontier teaching technology. Group frontiers are defined as the boundaries of restricted technology sets, where the restrictions derive from lack of educational infrastructures and/or other features of the production environment as mentioned above. Meanwhile, a common metafrontier is depicted as an unrestricted teaching technology set and this overarching metafrontier envelops group frontiers (O’Donnell, Rao, \& Battese, 2008). The metatechnology ratio is depicted as the distance in the efficiencies between their own frontier and metafrontier teaching technology. This ratio allows assessment of how well universities and colleges operate using their respective teaching technology under a general scenario represented by the metafrontier.

Bulter and Hamnett (2007) asserted that the geography of education plays an important role in educational attainment. Some areas may have better building, facilities or more qualified teacher than others. Therefore, this can produce marked differences in the pattern of outcomes. Moreover, Colburn and Horowitz (2003) argued that private education is considered as a substitute for public education. The degree to which learners seek alternatives to public education may reduce the demand for public TEIs. In this sense, it is worth examining what differences in the performance of TEIs based on two contextual factors pertained to Vietnamese university and college groups: location and ownership.

Our paper uses the metafrontier directional distance function approach to the Vietnamese higher education sector to better understand how well different groups, universities and colleges operate under the common framework. This approach can be applied not only in the context of education sector, but also to different areas including manufacturing, management and services, where a series of subgroups are operating in the same system. The metatechnology ratios are of considerable interest to managers and policy makers to make a decision of improving the performance of firms from changes in the production environment (O’Donnell et al., 2008).

The structure of the study includes the following sections. Section 1 briefly presents a literature review on the use of the directional distance function and the metafrontier framework in recent years. Section 2 introduces the methodology developed in this paper including the directional distance function approach in a metafrontier framework. This is followed in Section 3 with its application in Vietnamese higher education including discussion of the dataset, the variables, and the empirical results. The last section includes implications and conclusions of our empirical findings. 


\section{Review of studies on efficiency of higher education and the metafrontier approach}

Assessing the performance of TEIs has recently attracted much attention of researchers. Given that the tertiary education sector not only employs a variety of input resources to generate different academic outputs, but it also demonstrates differences in production technology, undertaking empirical analyses of efficiency and productivity is often difficult and complicated (Carrington, Coelli, \& Rao, 2005; Emrouznejad \& Thanassoulis, 2005). The recent empirical studies using DEA to assess efficiencies of TEIs have mostly assumed that all decision-making units (DMUs) share the same technology. However, this supposition may be inappropriate when different groups of TEIs face heterogeneous technological limitations (Beltrán-Esteve, Gómez-Limón, Picazo-Tadeo, \& Reig-Martínez, 2014; Chiu, Lu, Tsang, \& Chen, 2013). Efficiency under technological heterogeneity has been studied in the higher education sector by assessing heterogeneous frontiers for various subgroups of TEIs. Nevertheless, granted that the efficiency scores of subgroups was measured based on different frontiers, it is impossible to compare these scores across groups. The metafrontier approach considers an unconstrained framework being available to all groups and allows to assess a difference in teaching technology across types of TEIs regarding their operational efficiency.

Chambers, Chung, and Färe (1998) proposed a method of the directional distance that provides an additive measure of technical efficiency that allows one to seek to simultaneously expand output quantities and reduce input quantities. Daraio, Bonaccorsi, and Simar (2015) applied the directional distance approach to measure efficiency and economies of scale and specialisation in higher education institutions in Europe. In this paper, the authors used a large database of 2008 built by the European Universities Micro Data Consortium. Their findings indicated that size and specialisation have a significant influence on the efficiency of the modern organisational model of universities whereas specialisation has not a significant impact on the efficiency of the research model. However, the authors suggested a further research to confirm their initial findings and developing a robust method is necessary for the data quality analysis coming from different sources. Barra and Zotti (2016) used the directional distance method to analyse the teaching-related output efficiency for 72 Italian universities for the period of $2003 / 04$ to $2007 / 08$. Their empirical results revealed that the efficiency of all universities was on average 0.72 and approximately $50 \%$ of the universities having the efficiency score over the sample mean. In addition, they pointed out that private universities performed better than their public counterparts and that institutions in the Central-North area of Italy outperformed those in the Southern area. The authors also suggested that future studies may improve their findings by using bootstrap techniques in the directional distance approach.

The metafrontier framework has been developed to analyse differences in productivity of firms. This method originated from the studies of Hayami (1969), Hayami and Ruttan (1970) to illustrate the relationship between inputs and outputs of agricultural production units. Then, the metafrontier approach was introduced to a stochastic frontier analysis (Battese \& Rao, 2002; Battese, Rao, \& O’Donnell, 2004) and a DEA framework (O’Donnell et al., 2008) as an alternative to stochastic frontier analysis for estimating group frontiers and 
metatechnology ratios. The latter has been increasingly applied in analysing efficiency in different sectors such as hospitality, industry, and environment (Beltrán-Esteve et al., 2014; Chiu et al., 2013; Hsiao, Chern, \& Yu, 2012; Yu \& Choi, 2015).

As for higher education, Wongchai, Liu, and Peng (2012) investigated the regional differences in technical efficiency of 77 national universities in Thailand, using a DEA metafrontier model for the cross-sectional data of 2011. The findings revealed that technical efficiency and technological gap ratios from different regions varied widely from the metafrontier technical efficiency and that not any regional frontier is able to reach the metatechnology since the technological gap ratios are still found in every region. This implied that the performance of Thailand national universities could potentially be enhanced in the future. It is noted that this study only focused on a single year thus did not capture changes over multiple periods. Moreover, dividing 77 national universities into five groups led to a small sample size for each group as compared to total variables used in the models, which would reduce the power of analysis in these models.

Using the metafrontier cost function analysis, Lu and Chen (2013) estimated the cost efficiency of 60 institutes of technology (ITs) and 29 universities of technology (UTs) in Taiwan for a period of six years. The empirical results showed that the UTs had a higher cost-exploiting and cost-controlling capacity for the operations than the ITs, and that public and private schools for the UTs did not have wide variations in margin. The findings also implied that the UTs were significantly more efficient than the ITs. The authors suggested a further study on the quality dimension of the education business that would be useful to provide more information about the differences in cost-efficiency of two types of institutions.

Recently, Yaisawarng and $\mathrm{Ng}$ (2014) used the metafrontier DEA framework to evaluate the impact of the education reforms, so-called Project 211 on research efficiency of universities participating and non-participating this Project. Using dataset of 423 universities for 20072009, the authors showed that the performance of Project 211 universities was better than that of non-Project 211 universities and that Project 211 was successful to strengthen the research capabilities of members in this project. The authors suggested to develop a standard set for categorizing research operations into groups based on their achievements for the aim of further assessing the influence of reforms and related relevant policies.

Integrating the directional distance function with the metafrontier framework has been implemented in recent studies to measure technological differences in the efficiencies of different groups. This integrated method has been conducted in some sectors of manufacturing, environment and energy, but not yet applied in higher education. Specifically, Hsiao et al. (2012) used the directional distance approach and a metafrontier framework to evaluate the efficiency of integrated circuit design firms with differences between technology groups. They adopted the theory of Chung, Färe, and Grosskopf (1997) and Färe and Grosskopf (2004) for the directional distance function and calculated the technological gap by the difference between the group frontier and the whole sample, which was different from the method of O'Donnell et al. (2008). Lin, Chen, and Chen (2013) used the directional distance method and the metafrontier framework proposed by Battese, Rao, and O”Donnell (2004) to estimate and analyse the technological gap in efficiencies for four income levels of all nations involved to provide a measure of environmental efficiency. Other recent applications of directional 
metafrontier DEA approach include Wang, Zhou, Zhao, and Shen (2014) and Beltrán-Esteve, Reig-Martínez, and Estruch-Guitart (2017).

Regarding Vietnamese higher education, some research on assessing the performance of TEIs has been conducted recently, including Tran and Villano $(2015,2017 \mathrm{a} ; 2017 \mathrm{~b} ; 2017 \mathrm{c}$ forthcoming) and Nguyen, Thenet and Nguyen (2015). However, these studies concentrated on assessing the individual performance of universities or colleges only without comparing the technical efficiencies between groups if placing them under the common teaching technology. To our best knowledge, no research has applied the directional distance function under the metafrontier framework in higher education to estimate the efficiencies of TEIs in terms of different sub-technology groups. This provides us with a strong motivation to fill the gap in the efficiency literature, particularly in the Vietnamese higher education context, to better understand technological and efficiency differences of two types of tertiary institutions, namely, university and college, and thus offer useful information for policy makers to find better solution to enhance the operational efficiencies of TEIs.

\section{Methodology}

The methodological approach presented in this study is based on integrating the directional distance function into the DEA metafrontier framework to measure teaching technology gaps between the different groups of TEIs.

Let $x=\left(x_{1 j}, \ldots, x_{n j}\right) \in \mathfrak{R}_{+}^{M}$ and $y=\left(y_{1 j}, \ldots, y_{m j}\right) \in \mathfrak{R}_{+}^{S}$ be the vectors of $n$ inputs and $M$ outputs, in turn. Assume that there are $K(>1)$ clusters of TEIs, each operating under different group-specific technologies and using $N$ inputs to produce $M$ outputs. The metafrontier is identified as the common boundary covering all group frontiers. According to O'Donnell et al. (2008), the overarching metafrontier technology is expressed as follows:

$$
T=\left\{\begin{array}{c}
(x, y): x \geq 0 \in L^{k}(y) ; y \geq 0 \in P^{k}(x) ; \\
\text { Subtechnology set } T^{k} \text { using } x \text { to produce } y, k=1, \ldots, K
\end{array}\right\},
$$

where $L(y)$ and $P(x)$ are the desirable feasible sets of input resources and production outputs corresponding to the metatechnology set $(T)$. These input and output technology sets are identified by the directional distance approach and their envelopment is called as the directional meta-distance function.

Let $g=\left(g_{x}, g_{y}\right) \neq 0_{M+S} \in T$, where $g_{x} \in \mathfrak{R}_{+}^{M}$ and $g_{y} \in \mathfrak{R}_{+}^{S}$, the directional distance technology based on Chambers et al. (1998) and Färe and Grosskopf (2000), is introduced as:

$$
\vec{D}_{T}\left(x, y ; g_{x}, g_{y}\right)=\sup \left\{\beta:\left(x-\beta g_{x}, y+\beta g_{y} \in T\right\}\right.
$$

The input and output vectors $(x, y) \in \mathfrak{R}^{N+M}$ are projected in the $g=\left(-g_{x}, g_{y}\right)$ direction, where $\left(g_{x}, g_{y}\right) \in \mathfrak{R}_{+}^{M+S}$. It is important to choose a direction for this projection.

For the choice of a direction, Färe, Grosskopf, and Margaritis (2008) suggested a range of different choices for the direction vectors. For this study, the directional vector of $\left(g_{x}, g_{y}\right)=(x, y)$ was chosen because, first, Vietnamese TEIs are assumed to be able to manage to simultaneously expand outputs and save inputs to obtain the frontier efficiency even though output expansion has to be within the confines of meeting the Government's 
requirements. Second, the operating scope and scale of TEIs are relatively different, thus, they have different ways to expand outputs and contract inputs. Accordingly, choosing the direction vector of $x$ and $y$ is feasible to reflect the real nature of academic operations of TEIs.

We supposed that TEIs are separated into $K(>1)$ groups because each cluster would present their own teaching technology. Restricted by resources, regulation or other external influences, TEIs in specific groups might be barred from selecting the complete combination of inputs and outputs under the common framework. Hence, the amalgamations of inputs and outputs available to TEIs in the $k^{\text {th }}$ group can be illustrated as follows:

$$
T^{k}=\left\{\begin{array}{c}
(x, y): x \geq 0 \in L^{k}(y) ; y \geq 0 \in P^{k}(x) ; \\
\text { TEIs in subgroup } k \text { use } x \text { to produce } y
\end{array}\right\},
$$

where $L^{k}(y)$ and $P^{k}(x)$ are the feasible sets of inputs and outputs with respect to the technology set of the $k^{\text {th }}$ group. The $K$ directional distance group frontiers are presented as:

$$
\vec{D}^{k}\left(x, y ;-g_{x}, g_{y},\right)=\sup \left\{\beta \in \Re:\left(x-\beta g_{x}, y+\beta g_{y}\right) \in T^{k}\right\} .
$$

In this paper, the variable returns-to-scale (VRS) approach is used to account for heterogeneity of operating environments.

Under a DEA VRS and following the approach of Aparicio, Pastor, and Vidal (2016), let us denote the unit to be estimated as $\left(x_{0}, y_{0}\right)$ and use $g_{0}$ instead of $g$. Accordingly, the piecewise reference directional metadistance technology of $T, \vec{D}_{T}\left(x, y ;-g_{x}, g_{y}\right)$, can be estimated by:

$$
\begin{aligned}
\text { Subject to } & \sum_{j=1}^{n} \lambda_{j 0} y_{r j} \geq y_{r 0}+\beta_{0} g_{y_{r 0}} ; \\
& \sum_{j=1}^{n} \lambda_{j 0} x_{i j} \geq x_{i 0}-\beta_{0} g_{x_{i 0}} ; \\
& \sum_{j=1}^{n} \lambda_{j o}=1 ; \lambda_{j 0} \geq 0 ; j=1, \ldots, n ; i=1, \ldots, m ; r=1, \ldots, s,
\end{aligned}
$$

where $\beta_{0}$ is a scalar and $\lambda_{j o}$ is the intensity variable for input contraction and output expansion.

For the group- $k$ frontier, the DEA VRS directional distance technology, $\vec{D}^{k}\left(x, y ;-g_{x}, g_{y}\right)$ is defined as:

$$
\begin{aligned}
\text { Subject to } & \sum_{j=1}^{n} \lambda_{j 0}^{k} y_{r j}^{k} \geq y_{r 0}^{k}+\beta_{0}^{k} g_{y_{r 0}}^{k} ; \\
& \sum_{j=1}^{n} \lambda_{j 0}^{k} x_{i j}^{k} \geq x_{i 0}^{k}-\beta_{0}^{k} g_{x_{i 0}^{k}}^{k} ; \\
& \sum_{i=1}^{n} \lambda_{j 0}^{k}=1 ; \lambda_{j 0}^{k} \geq 0, j=1, \ldots, n ; i=1, \ldots, m ; r=1, \ldots, s,
\end{aligned}
$$

where $k$ is the number of TEI groups. 
Following Bogetoft and Otto (2011), the directional distance function can be illustrated in relation with the Farell efficiency approach as

$$
\hat{\theta}_{V R S}=1-\vec{D}_{T}\left(x, y ;-g_{x}, g_{y}\right) \text { and } \hat{\theta}_{V R S}^{k}=1-\vec{D}^{k}\left(x, y ;-g_{x}, g_{y}\right),
$$

$\hat{\theta}_{V R S}$ is the estimated Farell efficiency scores, $0<\hat{\theta}_{V R S} \leq 1$.

Accordingly, the directional metatechnology ratio for the $k^{\text {th }}$ group of TEIs is expressed as:

$$
M T R^{k}=\frac{\hat{\theta}_{V R S}}{\hat{\theta}_{V R S}^{k}},
$$

where $M T R^{k}$ can be interpreted as the Farell efficiency score that is bounded by zero and one. With $M T R^{k}=1$, TEIs have full technical efficiency, otherwise they have some inefficiency. This representation is consistent with the expression of O'Donnell et al. (2008).

The pooled data were chosen to estimate a common frontier for universities and colleges, respectively, with an assumption of an unvarying best-practice technology in the short period of three years (Fried, Lovell, \& Schmidt, 2008). It should be noted that this option generates the periodical efficiency estimates for each TEI, all against the same standard, and trends in efficiency estimates of each TEI were of interest to us in order to assess the performance of TEIs in the reported periods.

\section{Application to Vietnamese higher education institutions}

The approaches outlined above were applied to a sample of 253 Vietnamese TEIs comprising 112 universities and 141 colleges in a balanced panel. Since the reporting system of Vietnamese higher education is incomplete and disjointed, our data obtained from MOET and the websites of individual TEIs only covered the period 2011-2013. The sampled TEIs were the ones that complied with the Government regulations to submit their annual reports to MOET for all three years. The number of TEIs in our sample represents 57 per cent of the total number of institutions currently in Viet Nam. Although a longer span of data would have been desirable, we expect our available dataset for the three years to provide useful information about the technological distance and efficiencies of the two groups of institutions, universities and colleges in Viet Nam. In addition, as previously stated, for the purpose of this paper focusing on technical efficiency of TEIs, education quality is beyond our consideration.

\subsection{Input and output variables}

In the efficiency literature, until now there has not been a definitive study to guide the selection of inputs/outputs in the DEA applied studies in higher education. Outputs can be commonly classified as teaching, research, and services. However, finding true measures for these dimensions is difficult regarding the goals, and their relative importance, for instance shortterm, intermediate or long-term policies and prospects in higher education (A. M. Bessent, E. W. Bessent, Kennington, \& Reagan, 1982; Ahn \& Seiford, 1993; Worthington, 2001). Hence, it is possible for researchers to select a set of desired outputs to reflect the sector or the setting examined with respect to the different inputs. In addition, the accepted theories 
for measuring efficiency can be used as a background to choose the inputs and outputs (Castano \& Cabanda, 2007a).

The production function was referred in this study in order to investigate the relationship between inputs and outputs. Based on the production theory, the general agreement on inputs of universities can be categorised as human and physical capital, and outputs as arising from teaching and research activities (Lindsay, 1982; Johnes, 1996). In general, controllable inputs directly involved in the production process and the outputs of particular interest to managers of TEIs are preferred to reflect the relative importance of the goals of the institutions. In the Vietnamese context, the variables for input resources include staff numbers for teaching and administration, floor area for academic spaces, and operating costs of the institutions. While teaching staff involve in academic operations, administration staff are responsible for non-academic activities, supporting the whole production process of institutions. One of the important factors for TEIs to obtain annual enrolment quotas is the construction area for learning purposes, being regulated by the Government. Operating costs were annually spent for TEIs' operations including teaching staff wages, student allowances, learning facility purchases, and other related academic costs. These input variables were also used in recent studies such as de Franca, de Figueiredo, and Lapa (2010), Miranda, Gramani, and Andrade (2012), Nguyen et al. (2015), Tran and Villano (2015, 2017a, 2017b, 2017c, 2017d, 2018 forthcoming).

Following the metafrontier model of O'Donnell et al. (2008) that used the same aggregated output and inputs (land, machinery, labour, fertiliser and livestock) for different four regions of 97 nations in the world, we used three outputs for universities and colleges: number of graduates, number of students enrolled, and research income. The number of graduates refers to students who leave with completed degrees at the end of each year. Students enrolled refer to the number of students enrolled in a given year. Under the production function, they are considered as input resource users of TEIs embodied in the process of teaching and research. These two variables should be not overlapped and correlated, in which the total enrolled students are considered as semifinished outputs who are using input resources of TEIs to finish their degree whereas the graduates are considered as finished outputs at the end of year and waiting for their graduation, thus the graduates would use less input resources than the total enrolled students. Sullivan et al. (2012) asserted that enrolments and completions have been shown to be important in labour market studies and thus omitting one can miss a critical output dimension. Therefore, these variables should be considered as outputs in assessing the performance of TEIs, which are consistent with Castano and Cabanda (2007a, 2007b), de Franca et al. (2010), Miranda et al. (2012), Thanassoulis, Kortelainen, G. Johnes, and J. Johnes (2011), and Nguyen et al. (2015), Tran and Villano (2015, 2017a, 2017b, 2017c, 2017 d, 2018 forthcoming).

It should be noted that in the universities' case, number of postgraduate students was converted to equivalent number of undergraduates using a model proposed by the Document 1325/2007/BGDDT-KHTC of MOET on instructions on identifying the imputed coefficients for students and teachers in higher education. Doing this allowed us to obtain consistency in the number of outputs of universities and colleges when placing them all in a common context. Granted that data for publications are unavailable, research output in this case is 
estimated by the takings from research-related activities of universities and colleges including scientific research, consultancy and technological transfer.

Table 1 shows the descriptive statistics of inputs and outputs used in the model. It can be seen that the number of students enrolled at the university degree was almost five times higher than that of the college degree. Some indicators showed significantly greater for universities relative to colleges because of differences in operating environments (Table A1). Some private universities and colleges had been new-established in recent years, thus they had no graduates at the point of time to submit their report to MOET, e.g. in 2011. Research income (an aggregate of scientific research, consultancy and technological transfer) of universities was five times higher than that of colleges, implying that universities have much more invested in research activities.

Table 1. Summary statistics on input and output variables

\begin{tabular}{|l|c|c|c|c|c|}
\hline & Unit & Mean & $\begin{array}{c}\text { Standard } \\
\text { deviation }\end{array}$ & Max & Min \\
\hline \multicolumn{5}{|c|}{$\begin{array}{c}\text { Universities } \\
\text { Inputs }\end{array}$} \\
\hline Floor area & $1,000 \mathrm{~m}^{2}$ & 28 & 32 & 326 & 1.59 \\
\hline Academic staff & Person & 375 & 307 & 2,123 & 44 \\
\hline Non-academic staff & Person & 154 & 125 & 718 & 35 \\
\hline Operating cost & Billion VND & 80 & 79 & 528.98 & 0.31 \\
\hline \multicolumn{5}{|c|}{ Outputs } \\
\hline Total students enrolled & Person & 9,842 & 9,622 & 46,264 & 65 \\
\hline Graduates & Person & 2,010 & 2,152 & 18,126 & 0 \\
\hline Research income & Billion VND & 16 & 36 & 344.54 & 0 \\
\hline \multicolumn{5}{|c|}{$\begin{array}{c}\text { Colleges } \\
\text { Inputs }\end{array}$} \\
\hline Floor area & $1,000 \mathrm{~m}^{2}$ & 13.3 & 9.2 & 89.312 & 0.981 \\
\hline Academic staff & Person & 129 & 70 & 494 & 30 \\
\hline Non-academic staff & Person & 54 & 21 & 167 & 17 \\
\hline Operating cost & Billion VND & 18 & 14 & 125.14 & 0.69 \\
\hline \multicolumn{7}{|c|}{ Outputs } \\
\hline Total students enrolled & Person & 2113 & 1553 & 7872 & 67 \\
\hline Graduates & Person & 554 & 448 & 2220 & 0 \\
\hline Research income & Billion VND & 3.6 & 9.9 & 144.76 & 0 \\
\hline
\end{tabular}

\subsection{Efficiencies of TEIs}

This section presents separately the empirical results of technical efficiencies of the two groups of TEIs, universities and colleges, with respect to specific-group technology and metatechnology for each TEI in the sample. The metafrontier technology ratios provide more insights on the production capacity of TEIs when placing them in the unrestricted technology. 


\subsubsection{Universities model}

Table 2 presents efficiency scores of universities in terms of group frontiers and metafrontier for the three years considered. As can be observed, when compared with the best-practice TEIs within their own group, the efficiencies of universities were on average at 0.837 , meaning that universities could potentially increase their average efficiencies by 16.3 per cent. However, this result is less than the efficiency scores of TEIs in some Asian nations such as the Philippines, Thailand and Malaysia, which are at $0.966,0.85$ and 0.843 , respectively (Castano \& Cabanda, 2007a; Husain, 2012; Wongchai et al., 2012).

It can be seen that in terms of group frontiers, the mean technical efficiencies of the universities decreased from 0.867 in 2011 to 0.816 in 2012, and then slightly increased in 2013 to 0.827 . The Hotelling's test indicated that variations in efficiencies of universities over the three years were significant at the $1 \%$ level of significance. The number of efficient universities varied across the three years. On average, the university group had five efficient TEIs.

Table 2. Technical efficiencies and metatechnology ratio of universities

\begin{tabular}{|c|c|c|c|c|}
\hline Year & 2011 & 2012 & 2013 & Overall \\
\hline \multicolumn{4}{|c|}{ Technical efficiencies in terms of group frontiers } & \\
\hline Mean & 0.867 & 0.816 & 0.827 & 0.837 \\
\hline Standard deviation & 0.143 & 0.153 & 0.137 & 0.124 \\
\hline Min & 0.424 & 0.362 & 0.376 & 0.387 \\
\hline $\operatorname{Max}$ & 1 & 1 & 1 & 1 \\
\hline Efficient universities & 36 & 19 & 17 & 5 \\
\hline \multicolumn{2}{|c|}{ Hotelling's test ${ }^{\mathrm{a}}$ (F value) } & & & $13.35^{* * *}$ \\
\hline \multicolumn{4}{|c|}{ Technical efficiencies in terms of the metafrontier } & \\
\hline Mean & 0.813 & 0.745 & 0.761 & 0.773 \\
\hline Standard deviation & 0.163 & 0.166 & 0.149 & 0.136 \\
\hline Min & 0.350 & 0.257 & 0.304 & 0.303 \\
\hline Max & 1 & 1 & 1 & 1 \\
\hline \multicolumn{2}{|c|}{ Hotelling's test (F value) } & & & $18.95^{* * *}$ \\
\hline \multicolumn{4}{|c|}{$t$ test for a difference between the meta- and group frontiers } & $0.00033^{* * *}$ \\
\hline \multicolumn{3}{|l|}{ Metatechnology ratios } & & \\
\hline Mean & 0.935 & 0.912 & 0.920 & 0.922 \\
\hline Standard deviation & 0.084 & 0.096 & 0.086 & 0.078 \\
\hline Min & 0.637 & 0.651 & 0.624 & 0.700 \\
\hline $\operatorname{Max}$ & 1 & 1 & 1 & 1 \\
\hline Efficient universities & 31 & 22 & 15 & 8 \\
\hline \multicolumn{2}{|c|}{ Hotelling's test (F value) } & & & $5.46^{* * *}$ \\
\hline
\end{tabular}

Note: ${ }^{a}$ Hotelling's statistic tests for equal means among the three years; ${ }^{* * *}$ denotes significance at the $1 \%$ level. 
These findings are similar to the findings of Tran and Villano (2017) using cross-sectional data for 50 universities in which variation in the efficiency scores of TEIs might result from the volatility in the Government policy. In fact, from 2011, the MOET advised TEIs to cut off their enrolment quotas for the business and education courses due to the shortage of employment in the labour market. This would have affected the performance of TEIs in general.

The average DEA metatechnology ratio for the universities model in Table 2 is about 0.922. This means that the existing output that can be produced using the minimum inputs of the universities and the teaching technology of universities is about $92.2 \%$ of the existing output that could be produced using the same inputs and technology represented by the metafrontier. In other words, universities could, potentially increase their efficiency by about $7.8 \%$ to obtain the full efficiency of one under the unrestricted teaching technology. There are eight universities with metatechnology ratios of one. These universities efficiently used inputs to produce outputs, which meant that they are efficient at both their group frontier and metafrontier framework. Figure 1 demonstrates the distribution plots of metatechnology ratios of universities across the three years. These distributions are quite dense towards to the value of one.

The technical efficiencies and metatechnology ratios of universities relative to production technology of different ownerships and locations are presented in Table 3. Public institutions appear to operate more efficiently than private institutions in terms of their own teaching technology. However, this difference is not statistically significant using the Kruskal-Wallis test.

The metatechnology ratios reveal that public universities tend to be more efficient than private ones in using the inputs to produce the outputs under the metatechnology. For example, public and private institutions obtained the average meta-technological ratios of 0.925 and 0.914 in turn, suggesting that public institutions could potentially increase their efficiencies by about $7.5 \%$ using the metatechnology, whereas private ones could potentially improve their efficiency by about $8.6 \%$ under the same metafrontier technology. However, the difference in the metatechnology ratio between public and private institutions is only statistically significant at the $10 \%$ level.

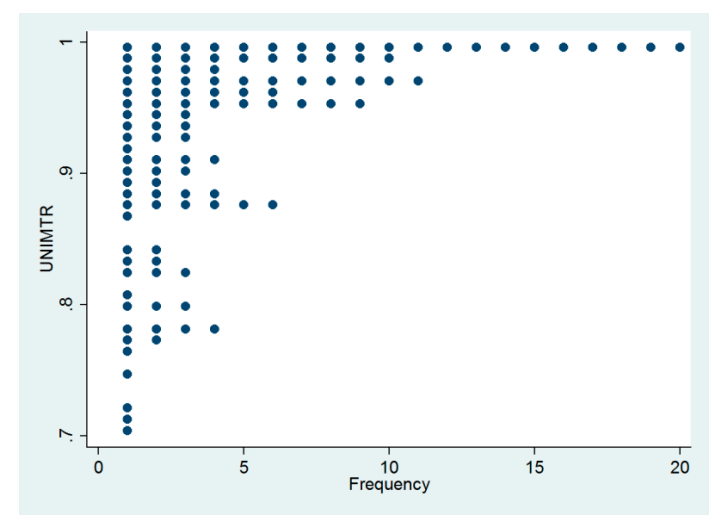

Figure 1. Distribution plots of metatechnology ratios of universities 
Table 3. Efficiencies and metatechnology ratio of universities classified by ownership and location

\begin{tabular}{|c|c|c|c|c|c|}
\hline & & 2011 & 2012 & 2013 & Overall \\
\hline \multicolumn{6}{|c|}{ Technical efficiencies relative to group frontiers } \\
\hline \multirow{3}{*}{ Ownership } & Public & 0.873 & 0.827 & 0.823 & 0.841 \\
\hline & Private & 0.851 & 0.786 & 0.835 & 0.824 \\
\hline & $\chi^{2}$ test $^{\mathrm{a}}$ & & & & 0.364 \\
\hline \multirow{3}{*}{ Location } & Urban & 0.877 & 0.827 & 0.823 & 0.842 \\
\hline & Rural & 0.852 & 0.800 & 0.832 & 0.828 \\
\hline & $\chi^{2}$ test $^{\mathrm{a}}$ & & & & 1.451 \\
\hline \multicolumn{6}{|c|}{ Technical efficiencies relative to the metafrontier } \\
\hline \multirow{3}{*}{ Ownership } & Public & 0.823 & 0.759 & 0.760 & 0.781 \\
\hline & Private & 0.786 & 0.707 & 0.764 & 0.752 \\
\hline & $\chi^{2}$ test & & & & 2.01 \\
\hline \multirow{3}{*}{ Location } & Urban & 0.831 & 0.767 & 0.759 & 0.786 \\
\hline & Rural & 0.785 & 0.714 & 0.764 & 0.755 \\
\hline & $\chi^{2}$ test & & & & $3.484^{*}$ \\
\hline \multicolumn{6}{|c|}{ Metatechnology ratio } \\
\hline \multirow{3}{*}{ Ownership } & Public & 0.940 & 0.914 & 0.922 & 0.925 \\
\hline & Private & 0.922 & 0.907 & 0.914 & 0.914 \\
\hline & $\chi^{2}$ test & & & & $2.87^{*}$ \\
\hline \multirow{3}{*}{ Location } & Urban & 0.945 & 0.926 & 0.922 & 0.931 \\
\hline & Rural & 0.920 & 0.891 & 0.916 & 0.909 \\
\hline & $\chi^{2}$ test & & & & $9.856^{* * *}$ \\
\hline
\end{tabular}

Note: ${ }^{a}$ The Kruskal-Wallis nonparametric rank test equality of populations; ${ }^{*}$ and ${ }^{* * *}$ denotes significance at the $10 \%$ and $1 \%$ levels, respectively.

The location of universities is of interest to us. This is because the location of urban universities is considered to be more advantageous as more modern facilities in teaching and learning can be accessed. They can thus attract more students and retain more qualified academic staff than their rural counterparts, which will contribute significantly to their operational efficiencies. The results in Table 3 reveal that there is no significant difference in group frontier efficiency scores between urban and rural universities. The meta-technology ratio further indicates that urban and rural universities will have the potential to improve their efficiency relative to the metafrontier by $6.9 \%$ and $9.1 \%$, respectively. This finding provide useful information for policy makers and enable them to design appropriate strategies to assist rural universities to improve their performance. 


\subsubsection{Colleges model}

Regarding the colleges model, with respect to their own group frontier, the efficiencies of colleges could be improved, on average, by $22.6 \%$. Hotelling's test revealed that variations in their efficiencies over the three years were significant at the $1 \%$ level. The number of efficient colleges varies over the reported periods. On average, there were 11 efficient colleges in the reported period.

The average DEA metatechnology ratio of colleges in Table 4 is about 0.95 , indicating that the existing output that is feasible using the college technology and the minimum inputs used by colleges is $95 \%$ of the output that could be achieved using the teaching technology represented by the metafrontier. This implies that colleges could, under the unrestricted teaching technology, potentially improve their efficiency by $5 \%$ to obtain full technical efficiency. While in reality colleges are operating under conditions that are more constrained than the universities, colleges showed a metatechnology ratio that was relatively good under the overarching teaching technology.

Table 4. Efficiencies and metatechnology ratio of colleges

\begin{tabular}{|c|c|c|c|c|}
\hline & 2011 & 2012 & 2013 & Overall \\
\hline \multicolumn{5}{|c|}{ Technical efficiencies in terms of group frontiers } \\
\hline Mean & 0.791 & 0.759 & 0.773 & 0.774 \\
\hline Standard deviation & 0.159 & 0.170 & 0.160 & 0.146 \\
\hline Min & 0.399 & 0.362 & 0.389 & 0.410 \\
\hline Max & 1 & 1 & 1 & 1 \\
\hline Efficient colleges & 25 & 17 & 18 & 11 \\
\hline \multicolumn{2}{|c|}{ Hotelling's test ${ }^{a}$ (F value) } & & & $7.54^{* * *}$ \\
\hline \multicolumn{5}{|c|}{ Technical efficiencies in terms of the metafrontier } \\
\hline Mean & 0.757 & 0.721 & 0.719 & 0.732 \\
\hline Standard deviation & 0.155 & 0.161 & 0.147 & 0.140 \\
\hline Min & 0.399 & 0.360 & 0.389 & 0.409 \\
\hline Max & 1 & 1 & 1 & 1 \\
\hline \multicolumn{2}{|c|}{ Hotelling's test (F value) } & & & $11.05^{* * *}$ \\
\hline \multicolumn{4}{|c|}{$t$ test for a difference between the meta- and group frontiers } & $0.014^{* *}$ \\
\hline \multicolumn{3}{|c|}{ Metatechnology ratios } & & \\
\hline Mean & 0.959 & 0.953 & 0.936 & 0.950 \\
\hline Standard deviation & 0.061 & 0.067 & 0.091 & 0.068 \\
\hline Min & 0.678 & 0.639 & 0.610 & 0.687 \\
\hline Max & 1 & 1 & 1 & 1 \\
\hline Efficient colleges & 50 & 42 & 48 & 22 \\
\hline \multicolumn{3}{|c|}{ Hotelling's test (F value) } & & $9.92^{* * *}$ \\
\hline
\end{tabular}

Note: a Hotelling's statistic tests for equal means among the three years; ${ }^{* *}$ and ${ }^{* *}$ denotes significance at the $1 \%$ and $5 \%$ levels, respectively. 
As can be seen, there were 22 colleges with the metatechnology ratio of one. These colleges efficiently used the input-output combinations that positioned them at the point of tangency between their group frontiers and the metafrontier technology. Figure 2 shows the distribution plots of metatechnology ratios of colleges across the three years. These distributions are quite dense and focus near the value of one.

Table 5 presents the technical efficiencies and metatechnology ratio of colleges classified by their ownership and location. It is surprising to see that private colleges were significantly more efficient than public ones relative to the group frontier in all three years at the one per cent significance level using the Kruskal-Wallis test. This result is consistent with the findings of Duh, Chen, Lin, and Kuo (2014) and Barra and Zotti (2016), that is, private institutions were significantly found to be more efficient than their public counterparts. Relative to the metafrontier technology, this difference is also statistically significant at the one per cent level.

By contrast, the metatechnology ratios illustrate that public colleges tended to be more efficient than private ones in using the inputs to produce the outputs under the metatechnology. For instance, the average metatechnological ratios of 0.953 and 0.927 for public and private colleges, respectively, which meant that the performance of the former could be improved by $4.7 \%$ using the metatechnology, whereas the efficiency of the latter could increase by about $7.3 \%$ under the same metafrontier technology. However, the difference in efficiencies of public and private colleges is not statistically significant.

On the other hand, the findings in Table 5 indicate that the performance of urban colleges is better than that of rural colleges in both group frontiers and meta-frontier framework at the one per cent significance level. Barra and Zotti (2016) came to the same conclusion that institutions located in big cities obtained higher efficiency scores. In the Vietnamese context, this backs up the fact that urban colleges have more advantages than rural colleges and are able to obtain higher efficiency in their operations via the larger number of students, higher revenues and more opportunities to get research funding. However, the metatechnology ratios revealed that under a common framework, the performance of urban colleges could increase by $9.6 \%$, while that of rural colleges could go up by 3.1 per cent using the same meta-technology.

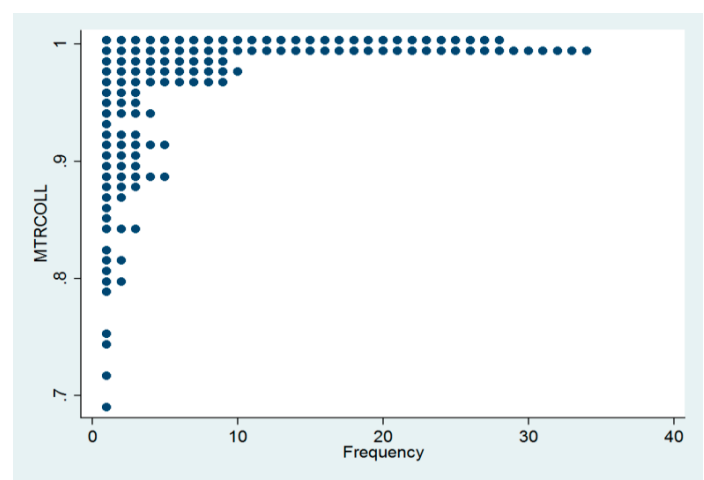

Figure 2. Distribution plots of metatechnology ratios of colleges 
Table 5. Efficiencies and metatechnology ratio of colleges classified by ownership and location

\begin{tabular}{|c|c|c|c|c|c|}
\hline & & 2011 & 2012 & 2013 & Overall \\
\hline \multicolumn{6}{|c|}{ Technical efficiencies relative to group frontiers } \\
\hline \multirow{3}{*}{ Ownership } & Public & 0.781 & 0.749 & 0.761 & 0.764 \\
\hline & Private & 0.869 & 0.833 & 0.864 & 0.856 \\
\hline & $\chi^{2}$ test $^{\mathrm{a}}$ & & & & $13.47^{* * *}$ \\
\hline \multirow{3}{*}{ Location } & Urban & 0.843 & 0.837 & 0.858 & 0.846 \\
\hline & Rural & 0.769 & 0.725 & 0.737 & 0.744 \\
\hline & $\chi^{2}$ test $^{\mathrm{a}}$ & & & & $33.44^{* * *}$ \\
\hline \multicolumn{6}{|c|}{ Technical efficiencies relative to the metafrontier } \\
\hline \multirow{3}{*}{ Ownership } & Public & 0.747 & 0.714 & 0.710 & 0.724 \\
\hline & Private & 0.831 & 0.772 & 0.782 & 0.795 \\
\hline & $\chi^{2}$ test & & & & $8.33^{* * *}$ \\
\hline \multirow{3}{*}{ Location } & Urban & 0.780 & 0.759 & 0.751 & 0.764 \\
\hline & Rural & 0.747 & 0.704 & 0.705 & 0.719 \\
\hline & $\chi^{2}$ test & & & & $6.64^{* * *}$ \\
\hline \multicolumn{6}{|c|}{ Metatechnology ratio } \\
\hline \multirow{3}{*}{ Ownership } & Public & 0.960 & 0.957 & 0.940 & 0.953 \\
\hline & Private & 0.948 & 0.924 & 0.907 & 0.927 \\
\hline & $\chi^{2}$ test & & & & 0.737 \\
\hline \multirow{3}{*}{ Location } & Urban & 0.926 & 0.908 & 0.880 & 0.904 \\
\hline & Rural & 0.973 & 0.973 & 0.960 & 0.969 \\
\hline & $\chi^{2}$ test & & & & $53.618^{* * *}$ \\
\hline
\end{tabular}

Note: ${ }^{a}$ The Kruskal-Wallis nonparametric rank test equality of populations; ${ }^{* * *}$ denotes significance level at $1 \%$.

\section{Conclusions}

The performance of Vietnamese higher education has attracted much interest of researcher in recent years. However, most studies have been implemented to measure the operational efficiency of universities and college only focused on individual performance of universities and colleges without consideration of their performance under an unrestricted framework. This paper aims to fill this gap by providing insights about technological heterogeneity and the efficiencies of the Vietnamese universities and colleges under the overarching teaching technology for the three years, 2011-2013. The DEA directional metafrontier framework was used to analyse technical efficiencies of TEIs with respect to their own teaching under the common framework. This method has contributed to the literature of higher education because it discovers technological heterogeneity that would remain veiled using the traditional DEA measure of the efficiencies of TEIs. 
The empirical findings yielded rich information for educational leaders and policymakers concerning the metatechnological efficiencies of the two categories of tertiary institutions in Viet Nam, namely, universities and colleges. The fact that higher education contributes significantly to enhancing the economic competitiveness of the nation supports the practical relevance of evaluating the operational efficiencies of universities and colleges. In addition, the findings are helpful in reducing asymmetric information when comparing the efficiencies of universities and colleges, and, thus, can provide more insights for the Government to accurately assess the role of universities and colleges, which operate under different teaching technologies, in the national higher education system.

Regarding metafrontier technical efficiencies of each TEI group, there is room for TEIs to improve their performance. Under own teaching technology, on average, the university group could potentially increase its efficiency by 16.3 per cent. The metatechnology ratios reveal that the management of inputs is related to technical inefficiencies of universities in the production of the outputs under the teaching technology represented by the metafrontier. This suggests that the university group could potentially increase its technical efficiencies by 7.8 per cent to obtain the metafrontier full efficiency. It is also worth highlighting that, under the unrestricted teaching technology, public universities are more efficient than private ones using the same teaching technology, and that the performance of urban universities is better than that of rural universities.

The college group could potentially increase its efficiency under the individual frontier by 22.6 per cent. It is interesting to see that the college group has a ratio of metatechnology of 0.95 , meaning that their efficiency could be enhanced by $5 \%$ to reach the frontier efficiency using their individual teaching technology represented by the metafrontier. Regarding the management of input resources to produce outputs measured by the metatechnology ratios, public colleges are inclined to be more technically efficient. Based on location, similar to the university case, urban colleges are more efficient than rural colleges. There is convincing evidence for this in the Vietnamese context.

The above results are relevant when it comes to some managerial implications. First, using their own teaching technologies, albeit universities (0.837) outperformed colleges $(0.774)$ at the $1 \%$ significance level $(p=0.00018)$, both of them are not efficient in their academic operations. Under the unrestricted metafrontier framework, the metatechnology ratios show that the gap between their own frontiers and metafrontier technologies is 0.078 and 0.05 for universities and colleges, respectively, at the $1 \%$ significance level $(p=0.0016)$. This implies that colleges used slightly better input resources to produce their outputs than universities did. In other words, it would seem to imply that colleges would be better off remaining in a college status when they are performing relatively well and have the comparative advantage in their curricular offerings. This may suggest that the status of upgrading colleges to universities in the past few years in Vietnam did not necessarily bring real improvement of performance of colleges themselves and the whole higher education system. Therefore, it is imperative to re-evaluate and examine the purpose and benefits obtained in the conversion of colleges into universities. It is beyond a change in the name, but should take into account how they can potentially improve their operational efficiency and enhance education quality. Additionally, to ensure the performance of the whole tertiary educations system, it is important for the 
government to revisit the function of each group in terms of their role, characteristics, contributions, and operational efficiencies as well as providing appropriate policies to keep and assist in improving their performance and education quality.

Lastly, our findings highlight the need to for appropriate policies such as land, capital assistance and human resource development policies and enabling environment to support private institutions and rural institutions to improve their performance as they work towards meeting world higher education standards.

This paper used the directional metafrontier approach to analyse the efficiencies of universities and colleges in the higher education sector in Viet Nam. However, future research may supplement our findings in various ways. First, we used panel data over a short period of three years; thus, changes in the technical efficiencies of TEIs over multiple periods could not be observed to offer a general picture of the operational efficiencies of TEIs. Accordingly, more data with multiple periods would be preferable to capture changes of TEIs over periods. Second, we examined indirectly the difference in efficiency scores of institutions based on two external factors, location and ownership, separately. We assumed that these two factors did not have a direct effects on production process of individual institutions. However, these exogenous factors may directly influence the performance of TEIs during the production process, and, thus, they should be included in a metafrontier framework as sub-frontiers. Given sufficient data, this would lead to a new direction in metafrontier methodology. Moreover, education quality should be considered if this construct is clarified and data are available. Finally, the robustness of the estimation procedures should be taken into account by investigating confidence intervals of the directional distance efficiency estimates by appropriate bootstrap methodologies in the context of metafrontier frameworks.

\section{References}

Ahn, T., \& Seiford, L. M. (1993). Sensitivity of DEA models and variable sets in a hypothesis test setting: The efficiency of university operations. In Y. Ijiri (Ed.), Creative and innovative approaches to the science of management (pp. 191-208). Connecticut, London: Quorum Books.

Aparicio, J., Pastor, J. T., \& Vidal, F. (2016). The directional distance function and the translation invariance property. Omega, 58, 1-3. https://doi.org/10.1016/j.omega.2015.04.012

Barra, C., \& Zotti, R. (2016). A directional distance approach applied to higher education: an analysis of teaching-related output efficiency. Annals of Public and Cooperative Economics, 87(2), 145-173. https://doi.org/10.1111/apce.12091

Battese, G. E., \& Rao, D. S. P. (2002). Technology gap, efficiency, and a stochastic metafrontier function. International Journal of Business and Economics, 1, 87-93.

Battese, G. E., Rao, D. S. P., \& O’Donnell, C. J. (2004). A metafrontier production function for estimation of technical efficiencies and technology gaps for firms operating under different technologies. Journal of Productivity Analysis, 21(1), 91-103. https://doi.org/10.1023/B:PROD.0000012454.06094.29

Beltrán-Esteve, M., Gómez-Limón, J. A., Picazo-Tadeo, A. J., \& Reig-Martínez, E. (2014). A metafrontier directional distance function approach to assessing eco-efficiency. Journal of Productivity Analysis, 41(1), 69-83. https://doi.org/10.1007/s11123-012-0334-7

Beltrán-Esteve, M., Reig-Martínez, E., \& Estruch-Guitart, V. (2017). Assessing eco-efficiency: A metafrontier directional distance function approach using life cycle analysis. Environmental Impact Assessment Review, 63, 116-127. https://doi.org/10.1016/j.eiar.2017.01.001 
Bessent, A. M., Bessent, E. W., Kennington, J., \& Reagan, B. (1982). An application of mathematical programming to assess productivity in the Houston independent school district. Management Science, 28, 1355-1367. https://doi.org/10.1287/mnsc.28.12.1355

Bogetoft, P., \& Otto, L. (2011). Benchmarking with DEA, SFA and R. New York: Springer. https://doi.org/10.1007/978-1-4419-7961-2

Bulter, T., \& Hamnett, C. (2007). The geography of education: Introduction. Urban Studies, 44(7), 11611174. https://doi.org/10.1080/00420980701329174

Carrington, R., Coelli, T., \& Rao, P. (2005). The performance of Australian Universities: conceptual issues and preliminary results. Economic Papers, 24(2), 145-163.

https://doi.org/10.1111/j.1759-3441.2005.tb01001.x

Castano, M. C. N., \& Cabanda, E. (2007a). Source of efficiency and productivity growth in the Philippine state universities and colleges: A nonparametric approach. International Business and Economics Research Journal, 6(6), 79-90.

Castano, M. C. N., \& Cabanda, E. (2007b). Performance evaluation of the efficiency of Philippine private higher educational institutions: Application of frontier approaches. International Transactions in Operational Research, 14(5), 431-444. https://doi.org/10.1111/j.1475-3995.2007.00599.x

Chung, Y., Färe, R., \& Grosskopf, S. (1997). Productivity and undesirable outputs: A directional distance function approach. Journal of Environmental Management, 51(3), 229-240. https://doi.org/10.1006/jema.1997.0146

Chambers, R. G., Chung, Y., Färe, R. (1998). Profit, directional distance functions, and Nerlovian efficiency. Journal of Optimization Theory and Applications, 98(2), 351-364. https://doi.org/10.1023/A:1022637501082

Chiu, C.-R., Lu, K.-H., Tsang, S.-S., \& Chen, Y.-F. (2013). Decomposition of metafrontier inefficiency in the two-stage network directional distance function with quasi-fixed inputs. International Transactions in Operational Research, 20(4), 595-611. https://doi.org/10.1111/itor.12008

Colburn, C. B., \& Horowitz, J. B. (2003). Local politics and the demand for public education. Urban Studies, 40(4), 797-807. https://doi.org/10.1080/0042098032000083812

Daraio, C., Bonaccorsi, A., \& Simar, L. (2015). Efficiency and economies of scale and specialization in European universities: A directional distance approach. Journal of Informetrics, 9(3), 430-448. https://doi.org/10.1016/j.joi.2015.03.002

de Franca, J. M. F., de Figueiredo, J. N., \& Lapa, J. D. S. (2010). A DEA methodology to evaluate the impact of information asymmetry on the efficiency of not-for-profit organisations with an application to higher education in Brazil. Annals of Operations Research, 173(1), 39-56. https://doi.org/10.1007/s10479-009-0536-1

Duh, R.-R., Chen, K.-T., Lin, R.-C., \& Kuo, L.-C. (2014). Do internal controls improve operating efficiency of universities? Annals of Operations Research, 221(1), 173-195. https://doi.org/10.1007/s10479-011-0875-6

Emrouznejad, A., \& Thanassoulis, E. (2005). A mathematical model for dynamic efficiency using data envelopment analysis. Applied Mathematics and Computation, 160(2), 363-378. https://doi.org/10.1016/j.amc.2003.09.026

Färe, R., \& Grosskopf, S. (2000). Theory and application of directional distance functions. Journal of Productivity Analysis, 13(2), 93-103. https://doi.org/10.1023/A:1007844628920

Färe, R., \& Grosskopf, S. (2004). Modelling undesirable factors in efficiency evaluation: Comments, European Journal of Operational Research, 57(1), 242-245.

https://doi.org/10.1016/S0377-2217(03)00191-7 
Färe, R., Grosskopf, S., \& Margaritis, D. (2008). Efficiency and productivity: Malmquist and more, in H. O. Fried, C. A. K. Lovell, \& S. S. Schmidt (Eds.), The measurement of productive efficiency and productivity growth (pp. 522-622). New York: Oxford University Press. https://doi.org/10.1093/acprof:oso/9780195183528.003.0005

Fried, H. O., Lovell, C. A. K., \& Schmidt, S. S. (2008). Efficiency and productivity. In H. O. Fried, C. A. K. Lovell, \& S. S. Schmidt (Eds.), Measurement of productive efficiency and productivity growth (pp. 3-91). New York: Oxford University Press, Inc.

Glewwe, P. (2004). An overview of economic growth and household welfare in Vietnam in the 1990s. In P. Glewwe, N. Agrawal, \& D. Dollar (Eds.), economic growth, poverty and household welfare in Vietnam (pp. 1-27). Work bank Regional \& Sectorial Studies.

Government Statistics Office. (2013). The 2013 Statistical Handbook. Retrieved from http://www.gso. gov.vn/default.aspx?tabid $=512$ \&idmid $=5 \&$ ItemID $=14944$

Hoang, T. (2013). Khong the de meo gia hoa cao trong giao duc [Impossible for a lack of discipline in upgrading from colleges to universities]. Retrieved from http://vnexpress.net/tin-tuc/xa-hoi/giaoduc/khong-the-de-meo-gia-hoa-cao-trong-giao-duc-2878045.html

Hayami, Y. (1969). Sources of agricultural productivity gap among selected countries. American Journal of Agricultural Economics, 51(3), 564-575. https://doi.org/10.2307/1237909

Hayami, Y., \& Ruttan, V. W. (1970). Agricultural productivity differences among countries. The American Economic Review, 60, 895-911.

Hsiao, B., Chern, C-C., \& Yu, M-M. (2012). Measuring the relative efficiency of IC design firms using the directional distance function and a metafrontier approach. Decision Support System, 53(4), 881-891. https://doi.org/10.1016/j.dss.2012.05.017

Husain, W. R. W. (2012). Comparative evaluation of public universities in Malaysia using data envelopment analysis (PhD Thesis). Warwick Business School, the University of Warwick, Conventy, England.

Johnes, J. (1996). Performance assessment in higher education in Britain. European Journal of Operations Research, 89, 18-33. https://doi.org/10.1016/S0377-2217(96)90048-X

Lin, E. Y.-Y., Chen, P.-Y., \& Chen, C. C. (2013). Measuring the environmental efficiency of countries: A directional distance function metafrontier approach. Journal of Environmental Management, 119, 134-142. https://doi.org/10.1016/j.jenvman.2013.01.015

Lindsay, A. W. (1982). Institutional performance in higher education: The efficiency dimension. Review of Educational Research, 52(2), 175-199. https://doi.org/10.3102/00346543052002175

London, D. J. (2010). Globalization and the governance of education in Vietnam, Asia Pacific Journal of Education, 30(4), 361-379. https://doi.org/10.1080/02188791.2010.520202

Lu, Y. H., \& Chen, K. H. (2013). Appraising the cost efficiency of higher technological and vocational education institutions in Taiwan using the metafrontier cost-function model. Research in Higher Education, 54(6), 627-663. https://doi.org/10.1007/s11162-013-9292-9

Miranda, R., Gramani, M. C., \& Andrade, E. 2012. Technical efficiency of business administration courses: A simultaneous analysis using DEA and SFA, International Transactions in Operational Research 19(6), 847-862. https://doi.org/10.1111/j.1475-3995.2012.00857.x

Ministry of Education and Training [MOET]. (2016). Statistics on universities in 2015-2016. Retrieved from http://www.moet.gov.vn/thong-ke/Pages/thong-ko-giao-duc-dai-hoc.aspx?ItemID=4041

Muszynski, B. (2008). Vietnam's challenging take-off. In Global Issues in the Contemporary World: Politics, Economics and Public Policy (pp. 328-343). Retrieved from http://www.uni-potsdam.de/sozpol/ fileadmin/.../Vietnam_s_Take-Off.pdf 
Nguyen, T. T. H., Thenet, G., \& Nguyen, K. M. (2015). Applying DEA sensitivity analysis to efficiency measurement of Vietnamese universities. Management Science Letters, 5, 983-992. https://doi.org/10.5267/j.msl.2015.9.002

Nguyen, N. S., \& Tran, T. T. T. (2009). Financing Vietnam's growth domestic and foreign sources of development. Vietnam Development Forum. Hanoi: Labor Publishing House.

O’Donnell, C. J., Rao, D. S. P., \& Battese, G. E. (2008). Metafrontier frameworks for the study of firmlevel efficiencies and technology ratios. Empirical Economics, 34(2), 231-255. https://doi.org/10.1007/s00181-007-0119-4

Pham, T. H. T. (2011). Doi Moi (renovation) and higher education reform in Vietnam. International Journal of Educational Reform, 20(3), 210-225.

Pham, V. L. (2013). Toi coi doi moi giao duc lan nay la tran danh lon [I asserted that restructuring education this time is an enormous fight]. Retrieved from http://vnexpress.net/tin-tuc/xa-hoi/giao-duc/ toi-coi-doi-moi-giao-duc-lan-nay-la-tran-danh-lon-2886136.html

Schwab, K. (2013). Global Competitiveness Report 2013-14. (Full data edition). Switzerland, Geneva.

Simar, L., Vanhems, A., \& Wilson, P. W. (2012). Statistical inference for DEA estimators of directional distances. European Journal of Operational Research, 220(3), 853-864. https://doi.org/10.1016/j.ejor.2012.02.030

Sullivan, T. A., Mackie, C., Massy, W. F., \& Sinha, E. (2012). Improving measurement of productivity in higher education. Washington, D.C: The National Academies Press.

Thanassoulis, E., Kortelainen, M., Johnes, G., \& Johnes, J. (2011). Costs and efficiency of higher education institutions in England: A DEA analysis. Journal of the Operational Research Society, 62(7), 1282-1297. https://doi.org/10.1057/jors.2010.68

Tran, C-D. T. T., \& Villano, R. A. (2015). Measuring efficiency of Vietnamese public colleges: An application of the DEA-based dynamic network approach. International Transactions in Operational Research, 25(2), 683-703. https://doi.org/10.1111/itor.12212

Tran, C-D. T. T., \& Villano, R. A. (2017a). An empirical analysis of the performance of Vietnamese higher education institutions. Journal of Further and Higher Education, 41(4), 530-544. https://doi.org/10.1080/0309877X.2015.1135886

Tran, C. D. T., \& Villano, R. A. (2017b). Input rigidities and performance of Vietnamese Universities. Asian Economic Journal, 31(3), 253-273. https://doi.org/10.1111/asej.12124

Tran, C-D. T. T., Crawford, M., \& Villano, R. A. (2017c). Efficiency-based ranking: A case of Vietnamese public universities. Asia-African Journal of Economics and Econometrics, 17(2): 197-215.

Tran, C-D. T. T., \& Villano, R. A. (2017d) (forthcoming). Environmentally-adjusted efficiencies of Vietnamese higher education institutions: a multi-stage bootstrap DEA method. International Journal of Operational Research.

Tran, C-D. T. T., \& Villano, R. A. (2018) (forthcoming). Financial efficiencies of Vietnamese public universities: A second-stage dynamic network data envelopment analysis approach. The Singapore Economic Review.

Wang, Q., Zhou, P., Zhao, Z., \& Shen, N. (2014). Energy efficiency and energy saving potential in China: A directional meta-frontier DEA approach. Sustainability, 6(8), 5476-5492. https://doi.org/10.3390/su6085476

Wongchai, A., Liu. W. B., \& Peng, K. C. (2012). DEA metafrontier analysis on technical efficiency differences of national universities in Thailand. International Journal on New Trends in Education and Their Implications, 3, 3-14.

World Bank. (2013). The Project of Higher Education Development Policy Program-Third Operation. Result framework. Retrieved from http://www.worldbank.org/projects/P116354/higher-educationdevelopment-policy-program-third-operation?lang=en 
Worthington, A. (2001). An empirical survey of frontier efficiency measurement techniques in education. Education Economics, 9(3), 245-268. https://doi.org/10.1080/09645290110086126

Yaisawarng, S., \& Ng, Y. C. (2014). The impact of higher education reform on research performance of Chinese universities, China Economic Review, 31, 94-105. https://doi.org/10.1016/j.chieco.2014.08.006

Yang, H., \& Pollitt, M. (2010). The necessity of distinguishing weak and strong disposability among undesirable outputs in DEA: Environmental performance of Chinese coal-fired power plants. Energy Policy, 38(8), 4440-4444. https://doi.org/10.1016/j.enpol.2010.03.075

Yu, Y., Choi, Y. (2015). Measuring environmental performance under regional heterogeneity in China: a metafrontier efficiency analysis. Computational Economics, 46(3), 375-388. https://doi.org/10.1007/s10614-014-9464-5

\section{APPENDIX}

Table A1. Statistical analysis of the difference in inputs and outputs of two groups

\begin{tabular}{|l|c|c|c|c|}
\hline \multirow{2}{*}{} & \multirow{2}{*}{ Unit } & \multicolumn{2}{c|}{ Mean } & \multirow{2}{*}{ t value $^{\mathrm{a}}$} \\
\cline { 3 - 4 } & & College & University & \\
\hline \multicolumn{5}{|c|}{ Inputs } \\
\hline Floor area & $1,000 \mathrm{~m}^{2}$ & 13.3 & 28 & $-8.13^{* * *}$ \\
\hline Academic staff & Person & 129 & 375 & $-16.72^{* * *}$ \\
\hline Non-academic staff & Person & 54 & 154 & $-16.24^{* * *}$ \\
\hline Operating cost & Billion VND & 18 & 80 & $-15.62^{* * *}$ \\
\hline \multicolumn{5}{|c|}{ Outputs } \\
\hline Total students enrolled & Person & 2113 & 9,842 & $-16.22^{* * *}$ \\
\hline Graduates & Person & 554 & 2,010 & $-13.89^{* * *}$ \\
\hline Research income & Billion VND & 3.6 & 16 & $-6.69^{* * *}$ \\
\hline
\end{tabular}

Note: ${ }^{a}$ the Student $\mathrm{t}$ distribution for testing the difference of two means; ${ }^{* *}$ at the $1 \%$ level of significance. 